\title{
Linking Reading and Writing in An English-As-A-Second-Language (ESL) Classroom for National Reorientation and Reconsruction
}

\author{
Olajide, Stephen Billy \\ English Education Unit \\ Department of Arts \& Social Sciences Education \\ University of Ilorin, Nigeria \\ Tel: 23-480-3964-2781 23-480-5667-8616 \\ E-mail: Olajide.Billy@Yahoo.Com / Billyolajide@Unilorin.Edu.Ng
}

\begin{abstract}
How developed, integrated and focused a nation has been is partly a function of her level of literacy. Hence, every nation desires full literacy that involves the two skills of reading and writing. Both skills are as elusive as they are rewarding, especially if they have to be acquired from a Second position, such as occupied by English in Nigeria. Over the years in the country, learner performance in the language has been a source of worry to the school system and other stakeholders. Nevertheless, the mutual, complementary teaching of the skills could make them fairly easy to acquire. This paper canvases that reading and writing be taught interactively in the English as the Second Language (ESL) context for effective learning.
\end{abstract}

Keywords: Reading, Writing, Reorientation, Reconstruction

\section{Introduction}

Reading and writing are the literacy skills, distinct from, but mutual with speaking and listening - the oral skills. Without the guide of a teacher, learning to read and write can be difficult (Olajide, 2000; Griffiths \& Parr, 2001). Quite a number of commentators and researchers have complained that all categories of learners of English as a Second Language (ESL) displayed difficulty in learning to read and write. For example, in Nigeria, Adegbija and Ofuya (1998) lamented poor reading and writing skills among a group of learners in a university, while Olajide (1991) found that, whatever their specializations, Nigerian university undergraduates showed difficulty with reading. Along the same line, and alluding to the findings by the Ford Foundations, Alebiosu (1997) asserted that most of the students in Nigerian tertiary institutions could not write well. James (1984) also reported that low motivation accounted for poor reading and writing skills among the undergraduates of Nigerian universities. Yet, as observed by Goodman (1967), Unoh (1985), Olajide (1991, 2009), Rose (1991) and Adegbija and Ofuya (1996), reading and writing are fundamental to intellectual and national development.

Reading and writing are structured and purposive arts. How a text is written affects how it will be read. As found by Olajide (1998) and Weber (2001), different disciplines are expressed in different ways, and learning each of the disciplines depends on the ability to suit reading to the type of text presented. May (1986) and Brent (1992) observed that a learner that cannot adopt the right approach to confronting a text may never be able to fully extract the information buried behind the print. In like manner, if he cannot identify, assess and sequence ideas back into print by way of writing, particularly at the higher level of learning, he would not achieve much.

Incidentally, adult learners that can read to write, and write to read efficiently in English is the dream of the Federal Government of Nigeria, a country that is that is in dire need of development and progress in all ramification. The country believes that education is an invaluable instrument of all forms of development and growth. She also believes that if majority of the citizens are efficient at English language skills, they will attain all round education. Consequently, the Government places a high premium on English in Education (Federal Republic of Nigeria, 2007). The entire world has become a global village undergoing re-ordering, and any country whose citizens cannot read and write well in a universal language may not compete well.

Thus, relying on the Nigerian experience, it may be counseled that teachers of English as a Second language should imbibe the methods and techniques that can ensure that learners read and write desirably. Apart from understanding the subject matters, the teachers must be abreast of socio-economic, cultural, political, and scientific developments around the larger world. When classroom activities on reading and writing successfully reflect such developments, learners are being prepared for international living (Stempleski, 1993; Griffiths \& Parr, 2001). 


\section{Some Psycholinguistic Considerations of Reading and Writing}

One possibly strong assumption is that reading cannot lead to understanding (comprehension) unless it involves the mental processing of the linguistic units and punctuation features of text. The reader must also appreciate the personality and attitude of the writer of the text (May, 1986; Brent, 1992). However, this assumption would not apply to reading beyond the written text; reading can actually take place far outside. Indeed, one can read the sky and predict that there would be rain or sun, or read a picture in order to write more than million words. What probably makes textual reading significant is that it is predominant in the school system and places far greater psycholinguistic thrust on the learner than any other form of reading.

Stressing the relationship between reading and writing, Pica (1986) suggested that the advanced learner of ESL may not do well in either without being sufficiently sensitized to the syntactic and rhetorical features of the text. Brent (1992) not only corroborated Pica, but added that the personal attributes of a writer as revealed from the target text could influence the reader's life, even long after reading the text. Thus, reading and writing, when carefully integrated, can become a means of promoting personal and collective ideals.

Goodman (1967) and Unoh (1985) emphasized the role of reading in intellectual development, and asserted that comprehension has a psycholinguistic foundation. In the same vein, Adegbija and Ofuya (1997) and Olajide (1999) reiterated the contributions of the punctuation and grammatical elements to effective writing. A poorly punctuated text is like tea without sugar; it would not attract the reader, as he or she would find it difficult to make textual as well as extra-textual meaning from the text. A writer with weak vocabulary and bad syntactic control will not be of help to his reader because good vocabulary helps to call up specific images in the reader's mind, while syntactic focus imposes rhythmic balance on the text and propels reading towards the desired meaning. Through effective paragraphing, the writer sequences ideas which the reader identifies, synthesizes, and applies in solving life's problem. The more complex the linguistic texture to of the written text, the higher the psychological thrust it places on the reader (Olajide, 1996); and any reading done is expected to improve the reader's ability.

It has been suggested that reading is less demanding than writing (Ashe, 1979; Olajide, 1999). However, it appears that the writer is his/ her own best teacher as no one can teach any one else how to write: the more individualized practice the learner-writer has the more refined his/her writing becomes. Hilgard, Atkinson and Atkinson (1971) and Landy (1976) observed that the ability to write well is a mark of advance learning. Ironically, year in year out, there have been complaints from English Departments of universities in the ESL context, worldwide that students do not write effectively. For example, Tinuoye (1993) complained that the students had problems with the correct uses of articles and prepositions. In order to develop effectively the learner's reading and writing skills, researchers in psycholinguistics have advocated that the-learning of both skills should be regularly examined (Brent, 1992, Borra, 1993, and Qiyi, 1993).

\section{Suiting Reading and Writing Instruction in the ESL Context to National Reorientation and Reconstruction Needs}

Now that the psycholinguistic underpinnings of reading and writing have been explained, it may be expedient to examine the need to suit instructions in both skills in English to the national reconstruction drives of Nigeria. That English is one language with a significant role to play in the life of the country is never an overstatement. After several decades of misrule by the military, Nigeria needs re-entrenchment among serious nations who had treated her as a pariah. She also needs to address the issues of marginalization raised by her various ethnic components. The need to diversify the economy is equally urgent. The unconditional development of English education is one of the things the country needs to encourage in order to attain the national reconstruction and international integration she badly desires. Most Nigerians do not like the ascendancy English enjoys in Nigeria education. However, language educators and linguists appreciate that it may not be easy to replace the language with a native language. While explaining the inadequacy of English as the country's lingua franca, Lawal (1989) cautioned that ' . . there are ... problems which are closely associated with language planning and policy which are considered as the most primordial and fundamental issues with which it is dangerous to tamper' (p.33). A very important question arises: even if Nigerians unanimously agree to evolve a native national language, which of the so many languages would be acceptable to all the citizens? Akinbobola (1998) reported the case of a Yoruba Director General and a Commissioner for Education in a Yoruba speaking State in the country, "who, by virtue of their offices, pronounced Yoruba as an elective subject both at the J.S.S and S.S.S. levels in the State" (p.41), contrary to the expectations of the people. This illustrates that speakers of the same language may not necessarily maintain the same attitude to the language. 
Thus, English seems to have come to stay in Nigeria. It may even be safe to assume that it already is a Nigerian language. According to Balatunde (2001), 'The language is caught between maintaining its native structure, texture and components and surrendering to the nature of the terrain on which it is moving' (p. iv). In the permanent contact existing between English and its host Nigerian environment, the language offers unique experiences. The situation can hardly be different as the entire world waxes into a global village owed to technological advancement. On the tendency of English to become a Nigerian language, Bobda (1995) maintained:

The fact that a national standard accent of English transcending ethnic boundaries is emerging in Nigeria is evidenced by the phenomenon where a given ethnic group may have a sound distinction like that of RP in their language and yet neutralize this in their English production (p.253).

If properly taught at all levels of education, English can be an extremely useful tool for enhancing the re-orientation and re-construction efforts of the country. Current national problems like poverty, identity, scientific and technological backwardness, revenue derivation and sharing, corruption, drug abuse, religious intolerance, pollution, and illiteracy can be tackled through reading and writing-related classroom activities in English, particularly at the advanced level of learning. The activities might influence the learners' views on such problems and mobilize them for appropriate action. It should be noted that one's command of language reflects the quality of one's thought and action. There are research evidences that reading and writing are genetically related to thinking (Olajide, 1996).

The model developed by the present writer and presented at the end of this paper (APPENDIX 1) may help to explain the assumption that reading and writing in English can be taught together to promote national reconstruction efforts. The model, informed by but different from Pica (1986) and Glassman (2002), seeks to integrate reading and writing in the context of national experiences where English is a second language. It tries to depict that both language skills are schematic and elastic, guaranteeing the inter-flow of relevant facts among the different. The clockwise movement of the national and English language boundary is intended to underscore the spatial, socio-cultural, linguistic and political determinants of reading and writing activities. Pica (1986) and Glassman (2002) were not directly concerned with reading and writing in ESL. While the one examined the cognitive dimensions of writing, the other advocated an inter-disciplinary approach to the development of language curriculum. However, both scholars have provided further insight into the fluid and perpetually interactive nature of the language arts which the present model seeks to elucidate.

\section{Obstacles to Integrative Development of Reading and Writing in the ESL Classroom}

Desirable as the integrative approach to the teaching of reading and writing may appear, it can be beset with a number of obstacles. Apart from that teachers of English, especially at the secondary school level in the ESL context restrict themselves to basal materials for the teaching of the skills, they hardly encourage their learners to engage in individualized reading and writing using self-selected materials. Playful drill on basal materials is a good way of teaching the language arts to young learners (May, 1986; Hills and Dubbyn, 1979), but how much of such a technique the teachers have mastered is not known. Also Anderson and Freebody (1981) found that conducive learning of oral skills leads to improved reading and writing. Yet, not all the basal materials used in the schools emphasize speaking and listening. The implication is that the teachers of English in Nigeria should adopt the integrative (language arts) approach to the teaching of reading and writing, so that learners can also speak and listen as they read and write in the classroom.

Besides, language teaching and learning is ever dynamic. Information provided by applied linguists about the nature of language and the way it is learnt often leads to pedagogical shifts. For instance, whereas it was fashionable in the western world in 1950's to stress imitation as a means of language learning (Christophersen, 1956), it is now believed that the learner's powers of observation (as to how people react to use) and creativity (by attempts at over-extension) guarantee language learning better (Weber, 2001). The teachers need to be exposed to the current theory and practices of English Language Teaching (ELT).

Home environment factors also affect language learning. The number of adults and siblings present in the home, how frequently and well they use English in conversations, the birth order or spacing of the children, the interest and affection shown by the surrounding adults, and communication facilities present in the home have implications for leaner performance in the language. The learner that enjoys access to the radio, television, telephone, magazines, newspapers, and family library is likely to speak, listen, read and write better than the one who does not. The latter would only rely on the limited opportunities given in the school to learn the skills. Hence, the dynamic English teacher has a way of improvising in his class, so that learner individual differences do not work against the less privileged. 
Even when they have relevant linguistic experiences, learners require an environment where they can build on what they have already learnt. They need pragmatic, semantic-syntactic and morphological reinforcements. Every young learner wishes to be able to influence his peers' behaviour with commands requests, questions, refusals; he desires to keep track of conversations (within and outside the classroom), and interpret tones correctly as he engages others in discussions. He also wants to give additional meaning to the words he has already learnt at home. Olajide (1998) argued that patterns of classroom discourse affect learning in the ESL situation. This implies that the teacher should pay attention to the social arrangements and preferences of learners, and that classroom activities should be as interactive as practicable.

Another serious obstacle is that many language teachers are insensitive to issues of the Nigerian environment. They probably feel that socio-political and economic problems should be left for the social scientists to address. The teachers hardly appreciate that if they imbibe democratic ideas in the organization and control of classroom activities, learning would be effective. An autocratic teacher will kill the instinct of his learners, while the democratic one would strive to develop such instinct. The latter always arranges his class very well, and links classroom activities with national and international issues, without failing to apply reward for good learner performance. Even when a learner fails to perform up to expectation, the teacher does not have to give him outright condemnation.

In the sprit of integration or holism, ESL classroom activities should enable the learners to speak, listen, read, write and engage in critical thinking desirably. The literature is replete with materials related to the techniques of teaching English language and literature (Lawal, 1995; Olajide, 2000 \& 2007). The efficient teacher should be mindful of the linguistic and psychological variables/characteristics of the learners while improving and developing adjunct materials for the class. Effort must also be made to sensitize the learners to their ecosystem. The closer the learners are to the environment, the better they appreciate nature and acquire the experiences they would need in their day-to-day communication tasks.

\section{Conclusion}

Reading and writing in the ESL context need to be developed and promoted in the educational system because they have implications for national reconstruction, integration, and progress. Available literature suggests that both skills are hardly linked effectively in the context. Nigeria is one example of such context: whereas she hopes to conquer poverty, attain balanced development and retain access to the global community using the English language, most of her citizens have not been able to read and write the language very well. In the country, university students who are expected to be models in English usage have been observed to be greatly deficient. Paradoxically, such students are expected to graduate to man the nation's economy which has been badly damaged by corruption and misrule. Government, teachers, parents, general lovers of education, and the learners themselves have great roles in the developing of the skills. The Nigerian experience suggests that the ESL teacher should have good knowledge of the subject matter, and be able to appreciate and reflect, where necessary, the reorientation and reconstruction needs of learners in selecting and implementing reading - writing activities in the classroom. In so doing, he should be abreast of the various techniques of teaching reading and writing interactively, without abandoning the other language skills of speaking and listening.

\section{References}

Adegdija, E. E. \& Ofuya, A. (Eds.) (1998). Introduction. English and Communication Skills for MESTA Students (pp. vii - ix). Ilorin, University of Ilorin: the Outer Circle Publishers.

Akinbobola, O.Y. (1998). Textbook writing and publishing in Nigeria language: Achievements and constraints. In O. Arohunmolase (Ed.), Nigerian Language for National Development and Unity, (p.41). Ibandan: Lolyem Communications.

Alebiosu, A.T. (1997). Writing skills. General Studies for Tertiary Institutions. Ilorin, University of Ilorin: Outer Circle Publishers.

Anderson, R. C. \& Freebody, P. (1981). Vocabulary knowledge. In J. Flood (Ed.), Comprehension and Teaching: Research Reviews (pp. 77-117). Newark, DE: International Reading Association.

Ashe, G. (1979). The art of writing made simple. London: W.H. Allen.

Babatunde, S. T. (Ed.). (2001). Contemporary English usage: An introductory Survey (pp. i - iv). Ilorin: Haytee Books.

Bobda, A.S. (1995). The phonologies of Nigerian English and Cameroonian English. In A.Bamgbose, A. Banjo, \& A. Thomas, (Eds.), New Englishes: A West African Perspective (pp.248 -268). Ibadan: Musuro Publishers. 
Brent, D. (1992). Reading as rhetorical invention: Knowledge, persuasion, and the teaching of research-based writing. Illinois: National Council of Teachers of English.

Christophersen, P. (1956). A course in English phonetics. London: Allen and Union.

Federal Republic of Nigeria (2007). National policy on Education. Lagos, NERDC Press.

Glassman, M. (2002).The integrative thematic curriculum. Retrieved May 26, 2007

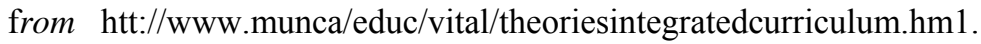

Griffiths, C. \& Parr, J. M. (2001). Language learning strategies: Theory and perception. ELT Journal, 55 (30), 247-254.

Hilgard, E. Atkinson, R \& Atkinson L. (1971). Psychology. New York: Harcourt Brace.

Hills, L.A. \& Dubbyn, M.A. (1979). A teacher training course for teachers of EFL: Lecturer's book. London: Cassell.

James,S. (1984). Reading for academic purpose: Study success series. Ibadan: BountyPress Limited.

Landy, J.V. (1976). Teaching students to write. Journal of Nigeria English Studies Associatio, (2),121,125.

Lawal, R.A. (1989). Towards the evolution of an indigenous national language for Nigeria. In R. A. Lawal \& A.

Olugbade (Eds.), Issues in contemporary African social and political thought, 1 (pp.32-39). Ibadan: Vantage Publishers Limited.

Lawal, R.A. (1995). The role of supervisors and inspectors in improving educational standard in language arts. Ilorin Journal of Studies in Education, 1 (3), 14-23.

May, F.B. (1986). Reading as communication: An interactive approach, second edition. Columbus: Merrill Publishing Company.

Olajide, S.B (1999). Essentials of communicative writing in English. Lagos: Frontline Publishers.

Olajide, S.B. (1998). Styles in scientific prose. In B. Lawal (Ed.) stylistics in theory and practice (pp. 98-111). Ilorin, university of Ilorin: Applied Linguistics Circle.

Olajide, S.B. (1991). Pattern of student performance in the "Use of English programme" at the Unversity of Ilorin. Unpublished M.Ed. Thesis, University of Ilorin.

Olajide, S.B. (1996). Reading-related skills of thinking in English among students of Nigerian colleges of education. Unpublished Ph. D. Dissertation, University of Ilorin.

Olajide, S.B. (2000). Introduction to language teaching methods. In Badmus, A. \& S. B. Olajide, (Eds.), A General Introduction to Language Studies. Ilorin: Kwara State College of Education, Ilorin, Nigeria.

Olajide,S.B.(2007).The Place of Folklore and Culture in Revitalizing Literacy for National Liberation. Paper Presented at the $5^{\text {th }}$ Pan-African Reading for All Conerence Held at the University of Ghana, Legon, Accra, Ghana, $6^{\text {th }}-10^{\text {th }}$ August, 2007.

Olajide, S. B. (2009). Types of reading. In V. A. Alabi \& S. T. Babatunde (Eds.), The Use of English in Higher Education. Ilorin: University of Ilorin, General Studies Division.

Olateju, M.A. (1998). Discourse analysis: Analyzing discourse in the ESL classroom. Lagos Crossland Education Services.

Pica, T (1993). An international approach to the teaching of writing. English Teaching Forum, 31(3) 6-9.

Qiyi, L. (1993). Peer editing in my writing class. English Teaching forum, (31), 330 - 31.

Rose, R. (1991). A comparison of an integrated curriculum approach and a traditional isolated subject matter approach to the same objectives in two grade and sixth grade classroom. Paper presented at the $40^{\text {th }}$ meeting of the National Reading Conference, Palm Springs, California, USA.

Stempleski, S. (1993). Linking the classroom to the world: the environment and EFL. English Teaching Forum, 31 (4), 2-11.

Tinuoye, M.O. (1991). Forum on common errors in usage and pronunciation: Confusion between 'their and 'there'. Journal of English as a Second Language, 3, 47-49.

Unoh, S.O. (1985). Moving towards the great intellectual milestone: A psycholinguistic view of learning to read and reading to learn. Literacy and Reading in Nigeria, 2. 
Weber, J. (2001). A concordance and genre-informed approach to ESL essay writing. ELT Journal, 55 (1), 14-20.

\section{APPENDIX 1}

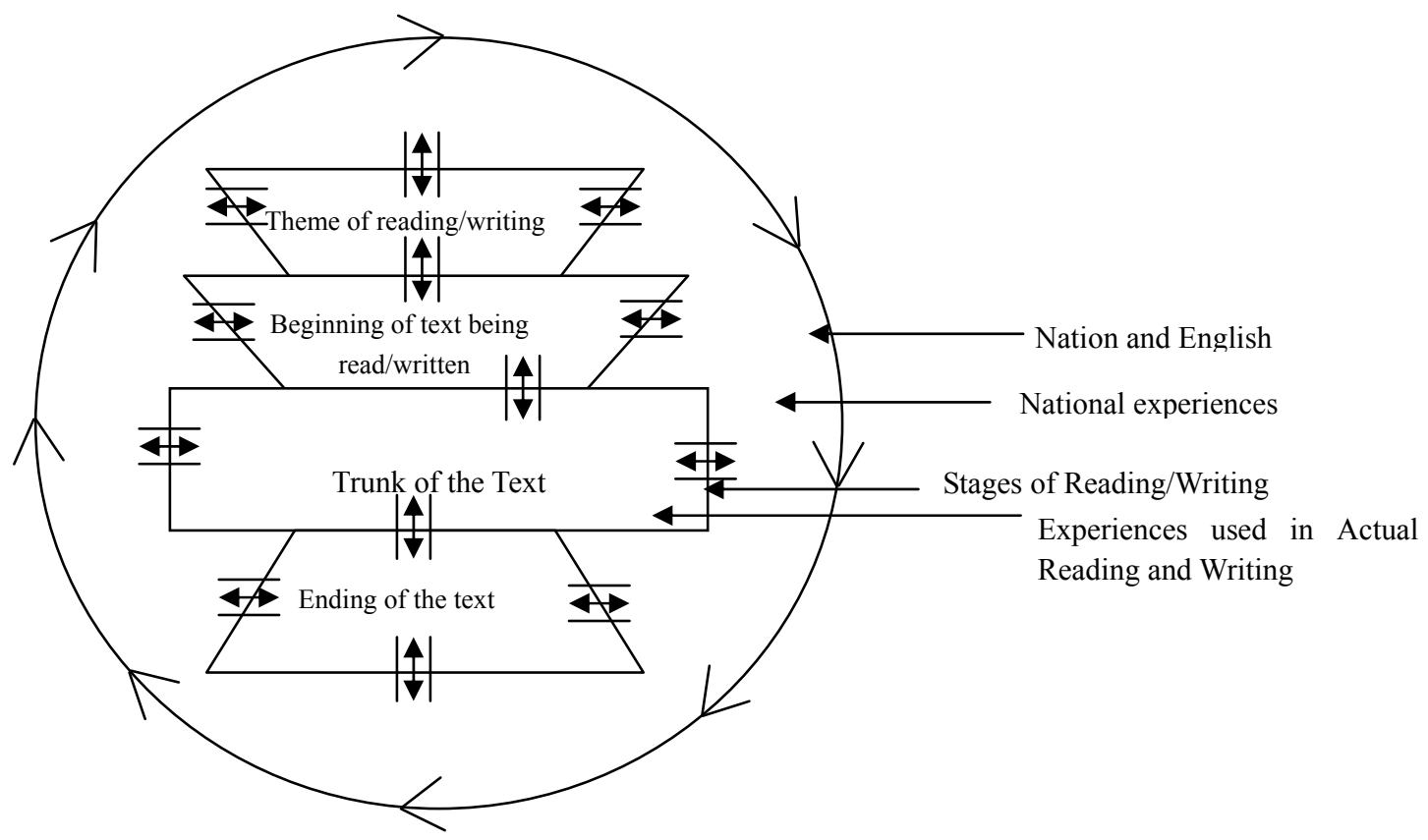

Figure 1. An integrative model of reading and writing in the ESL Context, developed by the present author for this paper.

\section{Affirmation to Editor}

I wish to affirm that the model (Appendix 1) in this paper is entirely my creation, although I have benefited from the theoretical views of some scholars that I have acknowledged in the body of the paper. Thus, the model can be published by your Journal without legal implication. The paper has not been published anywhere before now. Thank you, Sir/Madam.

(Signed)

Dr. S. B. Olajide,

Department of Arts and Social Sciences Education,

University of Ilorin, Nigeria 